Bangladesh J. Bot. 44(4): 557-564, 2015 (December)

\title{
PROTEOLYTIC BACILLUS SPP. ASSOCIATED WITH TANNERY INDUSTRIES: CONVENTIONAL AND MOLECULAR IDENTIFICATION
}

\author{
Mihir Lal Saha*, Tahsin Khan, Md Mostafa Kamal \\ aND Mohammad Nurul ISLam \\ Department of Botany, University of Dhaka, Dhaka-1000, Bangladesh \\ Key words: Bacteria, Bacillus, Tannery, Protease, Identification
}

\begin{abstract}
Samples collected from different stages of the tannery industry were found to be alkaline $(\mathrm{pH} 7.52$ to 12.11). A good number of bacteria were found to be associated with the samples. The bacterial count ranged in between $1.34 \times 10^{5}$ to $3.44 \times 10^{5} \mathrm{cfu} / \mathrm{ml}$ and $1.04 \times 10^{5}$ to $6 \times 10^{5} \mathrm{cfu} / \mathrm{ml}$ on nutrient agar (NA) and peptone yeast extract glucose agar (PYG) medium, respectively. The maximum bacterial count was observed in bating stage while the minimum count was in the deliming stage. Primarily, 70 isolates were selected based on their different colonial morphology. After heat shock test 27 isolates were finally selected for identification and proteolytic potential. All the selected isolates were the members of different species of the genus Bacillus. The conventionally identified species were B. stearothermophilus (9), B. subtilis (4), B. brevis (3), B. pumilus (3), B. alcalophilus (2), B. badius (2), B. firmus (2) and B. lentus (2). Four important proteolytic isolates of Bacillus were selected for molecular identification. The isolates were confirmed as Bacillus subtilis strain B20 (L/P/2/1), B. subtilis strain PB18 (D/P/3/1), Bacillus sp. strain BVC38 (D/P/3'/2) and $B$. amyloliqefaciens strain Egy $25\left(\mathrm{~B} / \mathrm{N} / 3^{\prime} / 1\right)$. Except $\mathrm{B} / \mathrm{N} / 3^{\prime} / 1$ all the conventional identification was in accordance with the molecular identification as the isolate $\mathrm{B} / \mathrm{N} / 3^{\prime} / 1$ was conventionally identified as $B$. pumilus $\left(\mathrm{B} / \mathrm{N} / 3^{\prime} / 1\right)$. All the isolates showed positive proteolytic activities on skim milk agar and the zone ratio was in between $2.61 \pm 0.44$ and $6.42 \pm 0.95$. These isolates could be commercially utilized in the tannery and detergent industries for their proteolytic activity.
\end{abstract}

\section{Introduction}

The tannery industry is one of the important industries in Bangladesh. About 150 tannery units i.e. $90 \%$ of the whole country are located at Hazaribagh of Dhaka. Bangladesh produces approximately $100-150$ million sq. feet of raw hides and skins, about $85 \%$ of which is exported in crust and finished form. The rest is used for producing leather goods to cater to the domestic market. The tanneries at Hazaribagh and its neighborhood reportedly discharge liquid and solid wastes. For the interaction between bacteria and leather processing, information is required on the types of bacteria found in effluents of the leather processing industries (Aunstrup 1979). Bangladesh and other South Asian countries produce and export leather as one of the major items which are mostly being processed by chemical treatment, resulting in inferior quality of products as well as environmental pollution. Use of alkaline protease in leather processing would be ecofriendly. The enzymatic dehairing and bating of hides have been widely accepted as a safe and sound alternative to the chemical process (Manachini et al. 1988).

Microorganisms are being used as a tool for production of biochemical and biologically active compounds mainly because of their abundant growth, higher productivity and lower production cost. The application of bacterial proteases is more significant when compared to the proteases from other sources like fungal (Anwar and Saleemudin 2000). Bacterial alkaline proteases are characterized by their high activity at alkaline $\mathrm{pH}$ and their broad substrate specificity. Effluent

*Author for correspondence: <sahaml@yahoo.com>. 
from leather processing industries might give us a good source of proteolytic bacilli. The genus Bacillus has a number of industrial importance and a good source of protease. Therefore, the present study was undertaken to isolate and identify Bacillus spp. associated with tannery industries and having proteolytic potential.

\section{Materials and Methods}

Hazaribagh tannery industries of Dhaka Metropolitan city, Bangladesh were selected for the present study. Samples were collected from the four selected stages viz. soaking, liming, deliming and bating. Sample water was collected in sterile plastic bottles sterilized with alcohol. The $\mathrm{pH}$ of the collected samples was measured in the laboratory by a pH meter (HM-31P, DKK-TOA Corp., Japan). Nutrient agar (NA) and peptone yeast extract glucose agar (PYG) media were used for the enumeration and isolation of aerobic heterotrophic bacteria present in samples. The $\mathrm{pH}$ of the medium was adjusted to 8.5. Enumeration and isolation of aerobic heterotrophic bacteria were carried out by serial dilution technique (Greenberg et al. 1998). The inoculated plates were inverted and incubated at $37^{\circ} \mathrm{C}$ for $48 \mathrm{hrs}$ in an incubator (Memmert $\mathrm{GmbH}+\mathrm{Co} \mathrm{Kg} 8540$ Sehwabach). After $48 \mathrm{hrs}$ of incubation the plates having well discrete colonies were selected for counting. Using colony counter (Digital colony counter, DC-8 OSK 100086, Kayagaki, Japan) the developed colonies were counted.

Preliminary selection of the isolates was made on the basis of their distinctive colony morphology. Heat-shock test was done for confirmation of spore former bacteria representing Bacillus spp. Bacteria grown on three different protein based media (Gelatin medium, Coagulated egg medium and Skim milk agar medium) were used for their proteolytic activity (Wandersman $e t$ al. 1986). For conventional identification important biochemical tests were carried out viz. carbohydrate fermentation, catalase, deep glucose agar, tyrosine degradation, egg-yolk lecithinase, starch hydrolysis, methyl red, nitrate reduction, citrate utilization, oxidase etc. (Collins and Lyne 1984, Eklund and Lankford 1967, Peltier et al. 1959 and Bryan 1950). Following Bergey's Manual (Sneath et al. 1986) conventional identification was done. Proteolytic activity was determined by the zone ratio on skim milk agar (SMA). For this purpose $1 \mathrm{ml}$ of sterilized milk was mixed with nutrient agar in sterilized Petri plate and allowed to solidify. Each of the isolates was point inoculated on SMA plate using sterilized inoculation needle and incubated at $37^{\circ} \mathrm{C}$ for $24 \mathrm{hrs}$. The isolates forming clear zone around the colonies were determined by $\mathrm{mm}$ scale. The following formula was used to determine the zone ratio.

\section{Zone ratio $=$ Zone diameter $(\mathrm{mm}) /$ Colony diameter $(\mathrm{mm})$}

Potential four proteolytic isolates were taken for molecular identification based on 16S rDNA sequence analysis. For the partial amplification of $16 \mathrm{~S}$ rDNA gene the following primer pairs were used- 5'-16S rRNA: CCAGACTCCTACGGGAGGCAGC, 3'-16S rRNA: CTTGTGCGGGC CCCCGTCAATTC. Supernatant of heat lysed cell suspension was used as the source of template DNA for PCR amplification of 16S rRNA gene. The following temperature and conditions were maintained for PCR amplification.

30 cycles $\left\{\begin{array}{llll}\text { Initial denaturation at } & 95^{\circ} \mathrm{C} & \text { For } & 5 \mathrm{~min} \\ \text { Denaturation at } & 94^{\circ} \mathrm{C} & \text { For } & 1 \mathrm{~min} \\ \text { Annealing at } & 55^{\circ} \mathrm{C} & \text { For } & 30 \mathrm{sec} \\ \text { Extension at } & 72^{\circ} \mathrm{C} & \text { For } & 1 \mathrm{~min} \\ \text { Final extension at } & 72^{\circ} \mathrm{C} & \text { For } & 10 \mathrm{~min}\end{array}\right.$


After completion of cycling program, the reactions were held at $4^{\circ} \mathrm{C}$. The amplified products were separated electrophoretically on $1 \%$ agarose gel. DNA bands were observed on UVtransilluminator and photographed by a Gel Documentation system (Microdoc DI-HD, MUV21254/365, Cleaver Scientific). The sequence generated from automated sequencing of PCR products were analyzed through NCBI-BLAST database (http://blast.ncbi.nlm.nih.gov/) and rRNA BLAST (http://bioinformatics.psb.ugent.be/cgi-bin/rRNA/blastform.cgi) programs to find out possible similar organism through alignment of homologous sequences.

\section{Results and Discussion}

Colour, $\mathrm{pH}$ and temperature of the samples are shown in the Table 1. Temperature of the collected samples ranged from 31 to $32^{\circ} \mathrm{C}$. The $\mathrm{pH}$ of the samples ranged in between 7.52 and 12.11. The maximum $\mathrm{pH}$ (12.11) was found in the liming stage while the minimum (7.52) was recorded in the soaking stage. Both NA and PYG were found to be suitable for enumeration and isolation of bacteria. The bacterial load ranged between $1.34 \times 10^{5}$ and $3.44 \times 10^{5} \mathrm{cfu} / \mathrm{ml}$ on NA and $1.04 \times 10^{5}$ and $6 \times 10^{5} \mathrm{cfu} / \mathrm{ml}$ on PYG, respectively (Table 2). The bacterial counts among the replicates were found to vary and the maximum mean bacterial count was observed in the bating stage $\left(3.68 \pm 1.90 \times 10^{5} \mathrm{cfu} / \mathrm{ml}\right)$ while the minimum was in the deliming stage $\left(1.33 \pm 0.27 \times 10^{5}\right.$ $\mathrm{cfu} / \mathrm{ml}$ ). Primarily, 70 bacterial isolates were isolated based on their different colonial morphology. Based on heat shock test (Thiel et al. 1999), 27 isolates were selected for identification and proteolytic potential. All the isolates showed positive proteolytic activity on three protein based media viz. coagulated egg albumin, gelatin (data not shown) and casein.

Table 1. Colour, pH and temperature of the collected samples.

\begin{tabular}{llcc}
\hline Stage & Colour & $\mathrm{pH}$ & Temperature $\left({ }^{\circ} \mathrm{C}\right)$ \\
\hline Soaking & Brown & 7.52 & 32 \\
Liming & Deep green & 12.11 & 31 \\
Deliming & Greyish green & 8.93 & 31 \\
Bating & Grey & 8.42 & 32 \\
\hline
\end{tabular}

Table 2. Bacterial count of different leather processing stages.

\begin{tabular}{|c|c|c|c|c|c|c|c|c|}
\hline \multirow{3}{*}{ Replicates } & \multicolumn{8}{|c|}{ cfu/ml of the collected samples in different leather processing stages } \\
\hline & \multicolumn{2}{|c|}{ Soaking } & \multicolumn{2}{|c|}{ Liming } & \multicolumn{2}{|c|}{ Deliming } & \multicolumn{2}{|c|}{ Bating } \\
\hline & NA & PYG & NA & PYG & NA & PYG & NA & PYG \\
\hline 01 & $1.34 \times 10^{5}$ & $2.22 \times 10^{5}$ & $2.39 \times 10^{5}$ & $2.13 \times 10^{5}$ & $1.75 \times 10^{5}$ & $1.04 \times 10^{5}$ & $1.53 \times 10^{5}$ & $1.76 \times 10^{5}$ \\
\hline 02 & $1.39 \times 10^{5}$ & $2.76 \times 10^{5}$ & $2.23 \times 10^{5}$ & $1.89 \times 10^{5}$ & $1.37 \times 10^{5}$ & $1.68 \times 10^{5}$ & $3.90 \times 10^{5}$ & $6.00 \times 10^{5}$ \\
\hline 03 & $1.45 \times 10^{5}$ & $2.39 \times 10^{5}$ & $2.11 \times 10^{5}$ & $1.72 \times 10^{5}$ & $2.01 \times 10^{5}$ & $1.37 \times 10^{5}$ & $3.44 \times 10^{5}$ & $4.39 \times 10^{5}$ \\
\hline 04 & $1.72 \times 10^{5}$ & $2.56 \times 10^{5}$ & $2.57 \times 10^{5}$ & $1.83 \times 10^{5}$ & $1.48 \times 10^{5}$ & $1.21 \times 10^{5}$ & $2.15 \times 10^{5}$ & $2.55 \times 10^{5}$ \\
\hline Mean $\pm \mathrm{Sd}$ & $\begin{array}{c}1.48 \pm \\
0.17 \times 10^{5}\end{array}$ & $\begin{array}{c}2.48 \pm \\
0.23 \times 10^{5}\end{array}$ & $\begin{array}{c}2.33 \pm \\
0.19 \times 10^{5}\end{array}$ & $\begin{array}{c}1.89 \pm \\
0.17 \times 10^{5}\end{array}$ & $\begin{array}{c}1.65 \pm \\
0.29 \times 10^{5}\end{array}$ & $\begin{array}{c}1.33 \pm \\
0.27 \times 10^{5}\end{array}$ & $\begin{array}{c}2.76 \pm \\
1.10 \times 10^{5}\end{array}$ & $\begin{array}{c}3.68 \pm \\
1.90 \times 10^{5}\end{array}$ \\
\hline
\end{tabular}




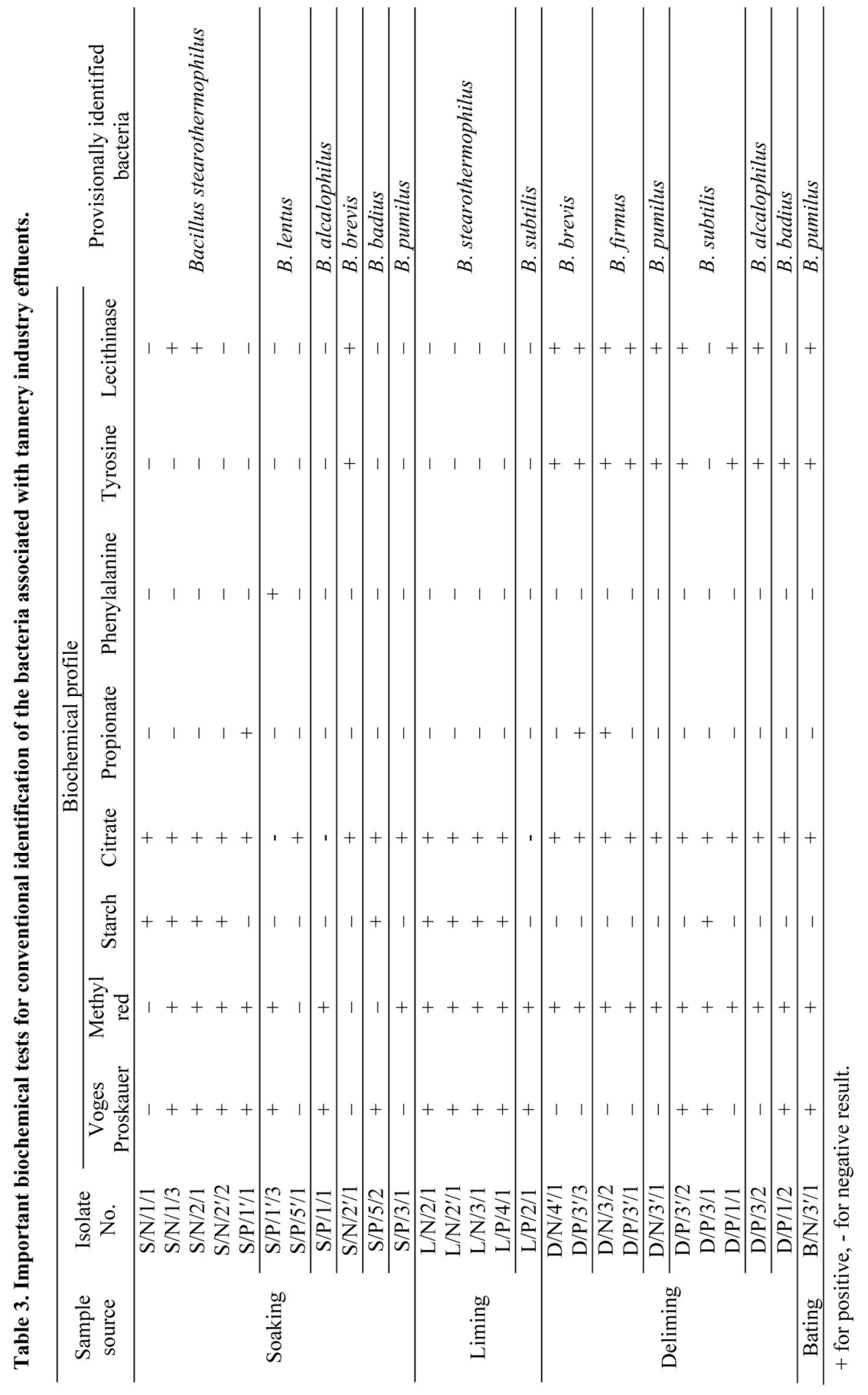


All the isolates were found to be Gram positive and spore formers. Important biochemical tests for conventional identification are shown in Table 3. Considering all the available morphological, microscopic and biochemical characteristics and following Bergey's Manual (Sneath et al. 1986) the isolated strains were conventionally identified. Selected 27 isolates belonged to the genus Bacillus. Under Bacillus there were 7 distinct species viz. $B$. stearothermophilus, B. subtilis, B. brevis, B. pumilus, B. alcalophilus, B. badius, B. firmus and $B$. lentus (Table 3). Saha et al. (2011) reported different Bacillus strains and one Micrococcus strain in the tannery effluents. Species frequency of the isolated Bacillus spp. is shown in Fig. 1. Bacillus stearothermophilus was found to be dominant among the isolated species.

Table 4. Protease activities on skim milk agar (SMA) medium measured as zone ratio.

\begin{tabular}{|c|c|c|c|c|}
\hline $\begin{array}{c}\text { Serial } \\
\text { No. }\end{array}$ & Bacteria & $\begin{array}{c}\text { Colony diameter } \\
(\mathrm{mm})(\text { Mean } \pm \\
\mathrm{Sd})\end{array}$ & $\begin{array}{l}\text { Zone diam. }(\mathrm{mm}) \\
\quad(\text { Mean } \pm \text { Sd })\end{array}$ & $\begin{array}{c}\text { Zone ratio } \\
\text { (Mean } \pm \mathrm{Sd} \text { ) }\end{array}$ \\
\hline 01 & $\begin{array}{l}\text { Bacillus } \\
\text { stearothermophilus }\end{array}$ & $11.00 \pm 2.65$ & $33.00 \pm 6.23$ & $3.07 \pm 0.60$ \\
\hline 02 & B. stearothermophilus & $11.67 \pm 1.53$ & $31.00 \pm 1.00$ & $2.68 \pm 0.31$ \\
\hline 03 & B. stearothermophilus & $4.33 \pm 0.58$ & $19.00 \pm 1.00$ & $4.45 \pm 0.75$ \\
\hline 04 & B. brevis & $7.33 \pm 1.53$ & $19.67 \pm 1.53$ & $2.73 \pm 0.35$ \\
\hline 05 & B. stearothermophilus & $8.67 \pm 0.58$ & $31.00 \pm 2.65$ & $3.60 \pm 0.57$ \\
\hline 06 & B. alcalophilus & $4.67 \pm 1.16$ & $29.67 \pm 6.51$ & $6.42 \pm 0.95$ \\
\hline 07 & B. stearothermophilus & $4.00 \pm 1.00$ & $14.00 \pm 2.65$ & $3.54 \pm 0.29$ \\
\hline 08 & B. lentus & $5.67 \pm 1.53$ & $31.33 \pm 4.62$ & $5.68 \pm 0.82$ \\
\hline 09 & B. pumilus & $9.00 \pm 1.00$ & $29.79 \pm 2.08$ & $3.31 \pm 0.18$ \\
\hline 10 & B. badius & $11.33 \pm 1.53$ & $33.33 \pm 2.89$ & $3.14 \pm 0.26$ \\
\hline 11 & B. lentus & $4.67 \pm 1.16$ & $23.00 \pm 2.65$ & $5.03 \pm 0.62$ \\
\hline 12 & B. stearothermophilus & $4.67 \pm 0.58$ & $18.67 \pm 1.53$ & $4.05 \pm 0.68$ \\
\hline 13 & B. stearothermophilus & $4.67 \pm 0.58$ & $19.00 \pm 2.65$ & $4.10 \pm 0.61$ \\
\hline 14 & B. stearothermophilus & $5.33 \pm 1.16$ & $18.67 \pm 0.58$ & $3.64 \pm 0.97$ \\
\hline 15 & B. subtilis & $4.00 \pm 1.00$ & $16.33 \pm 2.89$ & $4.14 \pm 0.48$ \\
\hline 16 & B. stearothermophilus & $4.67 \pm 0.58$ & $19.00 \pm 1.73$ & $4.13 \pm 0.81$ \\
\hline 17 & B. firmus & $13.33 \pm 1.53$ & $35.33 \pm 2.08$ & $2.67 \pm 0.24$ \\
\hline 18 & B. pumilus & $10.67 \pm 2.08$ & $32.67 \pm 3.22$ & $3.10 \pm 0.37$ \\
\hline 19 & B. brevis & $10.00 \pm 1.73$ & $34.33 \pm 3.79$ & $3.47 \pm 0.48$ \\
\hline 20 & B. subtilis & $9.67 \pm 2.08$ & $32.00 \pm 5.57$ & $3.33 \pm 0.30$ \\
\hline 21 & B. badius & $16.33 \pm 1.53$ & $40.67 \pm 4.51$ & $2.66 \pm 0.23$ \\
\hline 22 & B. subtilis & $10.33 \pm 1.53$ & $40.49 \pm 2.65$ & $3.92 \pm 0.26$ \\
\hline 23 & B. alcalophilus & $10.33 \pm 1.53$ & $26.67 \pm 3.22$ & $2.61 \pm 0.44$ \\
\hline 24 & B. firmus & $11.33 \pm 1.53$ & $37.00 \pm 2.65$ & $3.30 \pm 0.47$ \\
\hline 25 & B. subtilis & $9.67 \pm 1.16$ & $33.67 \pm 0.58$ & $3.51 \pm 0.37$ \\
\hline 26 & B. brevis & $10.33 \pm 1.53$ & $35.67 \pm 1.53$ & $3.49 \pm 0.36$ \\
\hline 27 & B. pumilus & $8.66 \pm 1.53$ & $30.67 \pm 8.08$ & $3.50 \pm 0.33$ \\
\hline
\end{tabular}




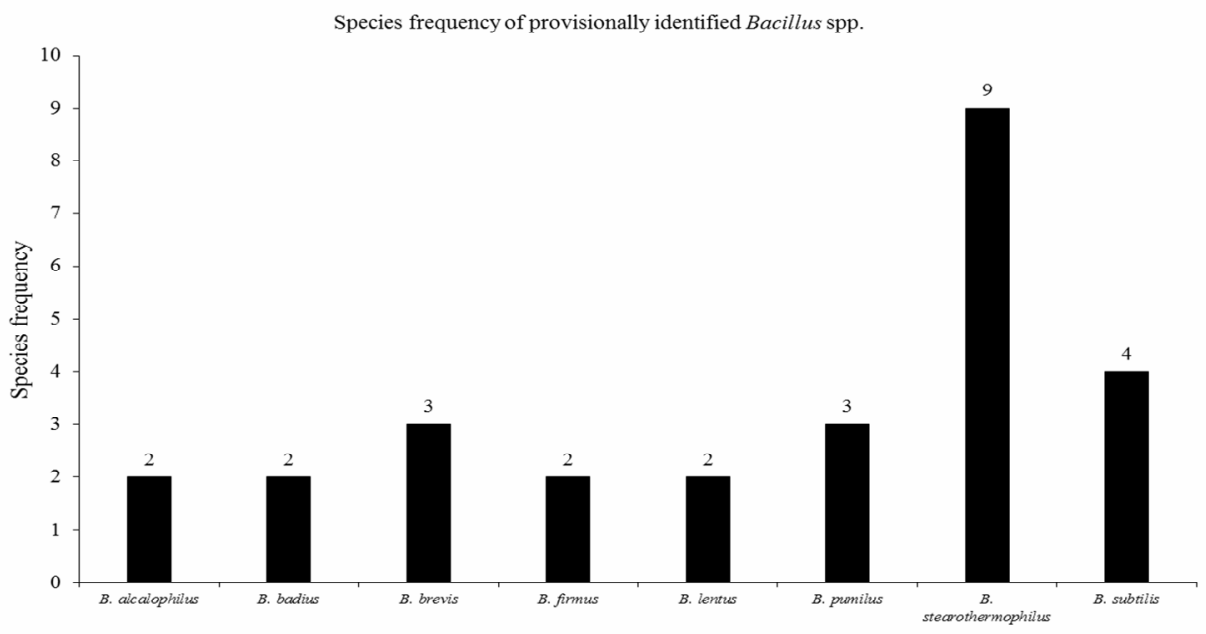

Fig. 1. Species frequency of provisionally identified Bacillus spp.

Protease activity on skim milk agar is shown in Table 4. All the isolates showed positive protease activities on casein with the zone ratio ranging between $2.61 \pm 0.44$ and $6.42 \pm 0.95$. Zone ratio of more than 5 was observed in B. lentus (S/P/5'/1 and $\left.\mathrm{S} / \mathrm{P} / 1^{\prime} / 3\right)$ and $B$. alcalophilus (S/P/1/1). The highest zone ratio $(6.42 \pm 0.95)$ was observed in case of $B$. alcalophilus $(\mathrm{S} / \mathrm{P} / 1 / 1)$ which was isolated from the soaking stage. Saha et al. (2011) reported proteolytic bacteria in the tannery effluents with the zone ratio ranged in between 1.5 and 5.8. In the present study, the isolated Bacillus strains were found to be better zone ratio (2.67 to 6.42) than the report of Saha et al. (2011). Skim milk agar plate method was demonstrated to be effective in the screening of large number of proteolytic microorganisms (Wandersman et al. 1986, Lin et al. 1992).

Table 5. Comparison between conventional and molecular identification of selected isolates.

\begin{tabular}{lllccc}
\hline Isolate & $\begin{array}{l}\text { Conventional } \\
\text { No. }\end{array}$ & \multicolumn{3}{l}{ Molecular identification } \\
\cline { 3 - 6 } & & Scientific name & Strain & $\begin{array}{c}\text { Identity match } \\
(\%)\end{array}$ & $\begin{array}{c}\text { Max. coverage } \\
\text { score }\end{array}$ \\
\hline L/P/2/1 & Bacillus subtilis & B. subtilis & B20 & 89 & 309 \\
D/P/3/1 & B. subtilis & B. subtilis & PB18 & 97 & 861 \\
D/P/3'/2 & B. subtilis & Bacillus sp. & BVC38 & 91 & 579 \\
B/N/3'1 & B. pumilus & B. amyloliqefaciens & Egy25 & 98 & 994 \\
\hline
\end{tabular}

There are numerous reports about different strains of Bacillus including B. alcalophilus, $B$. licheniformis, B. subtilis and B. thermobacter to produce alkaline protease (Kelly and Fogarty 1976, Shah et al. 1986, Manachini et al. 1988, Takii et al. 1990). Hameed et al. (1996) reported Bacillus subtilis isolated from tannery waste which could produce alkaline protease. Padmapriya et al. (2012) isolated Bacillus sp. from green mussel collected from Kanyakumari coast, having high protease activity.

Usually $B$. subtilis is considered to be non-pathogenic to human. Therefore, three better proteolytic strains $\left(\mathrm{L} / \mathrm{P} / 2 / 1, \mathrm{D} / \mathrm{P} / 3 / 1\right.$ and $\left.\mathrm{D} / \mathrm{P} / 3^{\prime} / 2\right)$ were selected for molecular identification. 
Similarly, one B. pumilus (B/N/3'/1) was selected for molecular identification. From the Fig. 2 we could see that, Lane $\mathrm{M}$ is the $1.0 \mathrm{~kb}$ ladder and lanes 1-4 are representing 4 different bacterial isolates $v i z$. $\mathrm{L} / \mathrm{P} / 2 / 1, \mathrm{D} / \mathrm{P} / 3 / 1, \mathrm{D} / \mathrm{P} / 3^{\prime} / 2$ and $\mathrm{B} / \mathrm{N} / 3^{\prime} / 1$. In the gel approximate size of the amplified DNA band was 600 bp. The bacterial isolate $\mathrm{L} / \mathrm{P} / 2 / 1$ was identified as Bacillus subtilis strain B20, the isolate $\mathrm{D} / \mathrm{P} / 3 / 1$ was identified as $B$. subtilis strain $\mathrm{PB} 18$, the isolate $\mathrm{D} / \mathrm{P} / 3^{\prime} / 2$ was identified as Bacillus sp. strain and the bacterial isolate $\mathrm{B} / \mathrm{N} / 3^{\prime} / 1$ was identified as B. amyloliqefaciens strain Egy25 (Table 5). Among four isolates three matched with their conventional identification except $B$. pumilus $\left(\mathrm{B} / \mathrm{N} / 3^{\prime} / 1\right)$. In case of molecular identification the conventionally identified $B$. pumilus was found to be B. amyloliqefaciens strain Egy25.

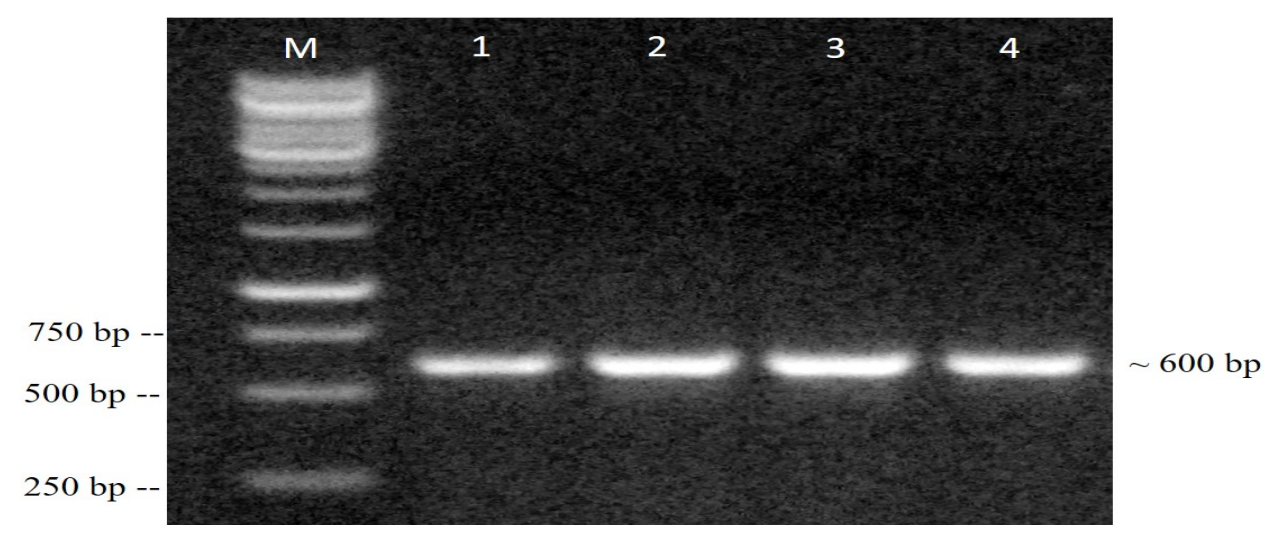

Fig. 2. PCR amplification of part of the $16 \mathrm{~S}$ rRNA gene.

At present enzymes find huge application in various industries. In tannery, alkaline protease has been involved in soaking and bating of skin. Although proteolytic enzymes are produced by many microorganisms, only a few bacteria and fungi could secrete high quantity of proteases capable of extensive in vitro degradation of native milk protein casein. Extracellular proteases are known as the most secretary enzyme of the genus Bacillus (Nishiya and Imanaka 1990). Due to fast growth rate and easy of genetic manipulation, bacteria and their proteases have been receiving good attention.

The present findings showed that a varied species of Bacillus was found to be associated with the leather processing industries. The isolated Bacillus spp. clearly indicated a significant variety of proteolytic activity and these Bacillus spp. would be a good source of proteases for leather processing industries. More researches are to be needed for these isolated bacteria and optimization of their enzyme production as well as commercial utilization.

\section{References}

Anwar A and Saleemudin M 2000. Alkaline protease from Spilosoma obliqua: Potential applications in bio-formulation. Biotechnology and Appl. Biochem. 31(2): 85-89.

Aunstrup K 1979. Production isolation and economics of extracellular enzymes. Appl. Biochem. Bioeng. 2: 27- 68 .

Bryan AH 1950. Manual of Methods for Pure Culture Study of bacteria. Leaflet. I-X. McGraw Hill Book Co. Inc, New York.

Collins CH and Lyne PM 1984. Microbiological methods ( $5^{\text {th }}$ ed.). Butterworth and Co. Publishers Ltd. London. 448. 
Eklund C and Lankford CE 1967. Laboratory manual for general microbiology. Prentice-Hall International Inc. London. 299.

Greenberg AE, Connors JJ, Jenkins D and Franson MAH 1998. Standard methods for examination of water and wastewater $\left(20^{\text {th }}\right.$ ed.). APHA, Washington DC.

Hameed A, Natt MA and Evans CS 1996. Production of alkaline protease by a new Bacillus subtilis isolate for use as bating enzyme leather treatment. World J. Microbiol. Biotechnol. 12: 289-291.

Kelly CT and Fogarty WM 1976. Microbial alkaline enzymes. Proc. Biochem. 11: 3-9.

Lin X, Lee CG, Castle ES and Shih JCH 1992. Purification and characterization of keratinase from feather degrading Bacillus licheniformis strain. Appl. Environ. Microbiol. 58: 3271-3275.

Manachini PL, Fortina MG and Parini C 1988. Thermostable alkaline protease produced by Bacillus thermoruber a new species of Bacillus. Appl. Microbiol. Biotechnol. 28: 409-413.

Nishiya Y and Imanaka T 1990. Cloning and nucleotide sequence of Bacillus stearothermophilus neutral protease gene and its transcriptional activator gene. J. Bacteriol. 172: 4861-4869.

Padmapriya B, Rajeswari T, Nandita R and Raj F 2012. Production and purification of alkaline serine protease from marine Bacillus species and its application in detergent industry. E. J. Appl. Sci. 4(1): 2126.

Peltier GL, Georgi CE and Lindgren LF 1959. Laboratory Manual for General Bacteriology (5 ${ }^{\text {th }}$ ed.). John Wiley and Sons. Inc. London.

Saha ML, Begum KJMH, Khan MR and Gomes DJ 2011. Bacteria associated with the tannery effluent and their alkaline protease activities. Plant Tissue Cult. \& Biotech. 21(1): 53-61.

Shah DN, Shah VD, Nehete PN and Khotari RM 1986. Isolation of Bacillus licheniformis mutant from stable production profiles of alkaline protease. Biotechnol. Lett. 8: 103-106.

Sneath PH, Mair A, Sharpe ME and Holt JG 1986. Bergey's manual of systematic bacteriology $\left(9^{\text {th }}\right.$ ed. $)$. Williams and Wilkins Company, Baltimore. London.

Takii Y, Kuriyama N and Suzuki Y1990. Alkaline serine protease produced from citric acid by Bacillus alcalophilus sub sp. halodurans KP 1239. Appl. Microbiol. Biotechnol. 34: 57-62.

Thiel T, May VL, Kalk MR, Alters S, Alters B and O'Brian J 1999. Science in the real world: Microbes in action. University of Missouri, St. Louis.

Wandersman C, Andro T and Berthau Y 1986. Extracellular proteases in Erwinia chrysanthemum. Gen. Microbiol. 132: 899-906.

(Manuscript received on 5 April, 2015; revised on 20 August, 2015) 